\title{
North-east Asia interstate power grid expansion in the conditions of possible economic recession in China
}

\author{
Leonid N. Trofimov ${ }^{1}$, Ivan L. Trofimov ${ }^{1, *}$, Sergei V. Podkovalnikov ${ }^{1}$ \\ ${ }^{1}$ Melentiev Energy Systems Institute of Siberian Branch of the Russian Academy of Sciences, Electric Power Systems Department, \\ 664033, 130, Lermontova Str., Irkutsk, Russia
}

\begin{abstract}
The article considers scenarios of the prospective interstate power grid (ISPG) expansion in Northeast Asia with possible economic recession in China because of COVID-19 and other factors. Features of optimization of new capacities addition of renewable energy sources in the ISPG are considered. A series of computational experiments with variations in the profiles of wind and solar power plants were carried out. The assessment of impact the intermittence of renewable energy power output on the structure of ISPG was evaluated, with taking into account of possible economic recession in China. A comparative analysis of solutions to the problem of optimization of intermittent generation capacity inputs for scenarios with the formation of an energy connection in northeast Asia and its absence is carried out.
\end{abstract}

\section{Introduction}

In the laboratory of the Melentiev Energy Systems Institute is carried out the research to study of the prospective Interstate power grid expansion in the Northeast Asia [1-3]. The computing and geoinformation system developed by the authors is used, which contains a model for optimization of energy power systems and it operating modes (called ORIRES). In this model the optimization of generation capacities expansion and it operating modes are determined by the minimum cost of their construction, operation and fuel consumption, if all technical constrains are satisfied. Along with optimization of new capacities of thermal, nuclear and hydraulic power plants, the involvement of each type of power plants in covering graphs of daily and annual electric load is optimized too. The obtained installed capacities and generation profiles of these types of power plants are optimal in terms of minimizing total costs [4-7].

As a part of research of the interstate power grid expansion in Northeast Asia (NEA ISPG), the number of scenarios with the possible economic recession in China because of COVID-19 and other factors were calculated on the model and described in this paper.

\section{Base case scenarios with possible economic recession in China}

A number of computational experiments were carried out on the ORIRES model by using the Computing and Geoinformation System (the CIS).
Scenarios of the model optimize the structure of generating capacities for the non-connection electric power systems (EPS) and for the interstate power interconnection. For the target year (2040), the optimal additions of new generating capacity and the contribution of each type of power plants to electricity generation are calculated in order to cover the electricity demand for each country in the ISPG. Due to the global economic recession because of COVID-19 and other negative factors, the authors calculated scenarios with a significant decrease in energy consumption in China (the largest EPS in the Northeast Asia interstate power grid). In these scenarios the electricity consumption in China was reduced by $30 \%$. This assumption is based on a possible recession in the development of China's economy and energy, due to the negative impact of the COVID-19 pandemic and other factors.

Figure 1 shows the base case scenario with nonconnection power systems in Northeast Asia, with the possible economic recession in China.

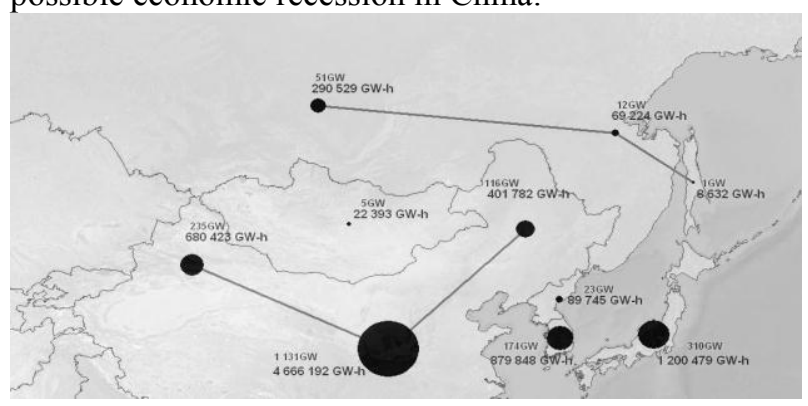

Fig. 1. Base case scenario, non-connection power systems, with possible economic recession in China.

* Corresponding author: $\mathrm{t}$ john88@,isem.irk.ru 
In the figures 1 and 2 show the following model nodes: Siberian EPS of the Russian Federation, East EPS of the Russian Federation, Sakhalin EPS of the Russian Federation, North-West EPS of China, North-East and Center EPS of China, North-East EPS of China, North Korea EPS, South Korea EPS and Japan EPS.

The second scenario optimizes the structure of generating capacities for the Northeast Asia interstate power grid (see Figure 2).

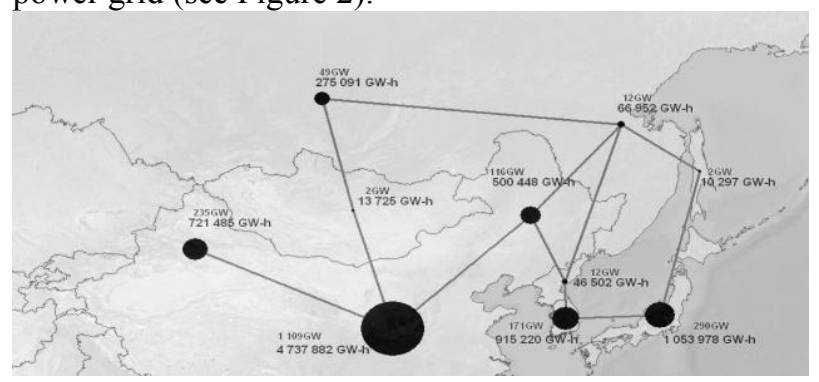

Fig. 2. Scenario 2, interstate power interconnection with possible economic recession in China.

In addition, due to the deterioration of the overall situation in the global economy, development options were tested on the model, assuming a significant reduction in the growth rate of energy consumption in China (as the largest EPS in the NEA ISPG). As an example, when calculating the development of ISPG for 2040 , the indicators of the estimated level of electricity consumption in China were reduced by $30 \%$, compared to the previously predicted ones. This reduction was made by experts based on the existing and possible future rates of economic and energy development in China, due to the negative impact of the COVID - 19 pandemic.

The formation of ISPG makes it possible to pass peak loads in each country by importing electricity from neighbouring countries. At the same time, the additions of new installed capacities in each country are decreasing. This is called the power integration effect.

Table 1 shows the results of calculating two base case scenarios: non-interconnected EPSs and interstate power interconnection with the possible economic recession in China. The bottom raw of the table shows the integration effect. The formation of NEA ISPG saves $\$ 31 \mathrm{Bln}$. in capital investments and $60 \mathrm{GW}$ of installed capacity.

Table 1. Benefits of the interstate power interconnection in Northeast Asia with possible economic recession in China.

\begin{tabular}{|c|c|c|c|c|c|}
\hline \multirow[t]{2}{*}{$\begin{array}{l}\text { Name of } \\
\text { scenario }\end{array}$} & \multicolumn{3}{|c|}{$\begin{array}{l}\text { Capital investments, } \\
\text { \$ Bln. }\end{array}$} & \multicolumn{2}{|c|}{ Capacity, GW } \\
\hline & $\begin{array}{l}\text { power } \\
\text { plants }\end{array}$ & $\begin{array}{l}\text { electri } \\
\text { c ties }\end{array}$ & Total & $\begin{array}{l}\text { installed } \\
\text { capacity }\end{array}$ & addition \\
\hline $\begin{array}{l}\text { Non- } \\
\text { connectio } \\
\mathrm{n} \quad \text { EPSs, } \\
\text { with } \\
\text { economic } \\
\text { recession } \\
\text { in China }\end{array}$ & 347 & 0.214 & 347.2 & 2058 & 301 \\
\hline $\begin{array}{l}\text { Interstate } \\
\text { power }\end{array}$ & 278 & 36 & 314 & 1998 & 241 \\
\hline
\end{tabular}

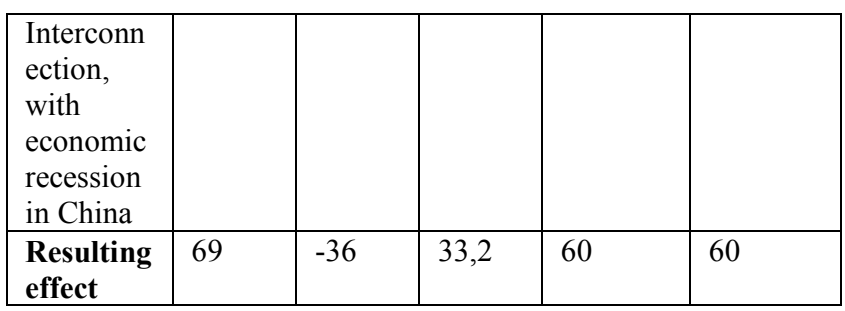

\section{Additional scenarios with $\mathrm{CO}_{2}$ emission taxes}

In addition to scenarios with the expected economic recession in China, the next three scenarios with an increase in the $\mathrm{CO}_{2}$ emission taxes were calculated.

The $\mathrm{CO}_{2}$ emission taxes were increased in these scenarios by $\$ 30,40$ and 60 per ton, respectively [8]. Based on this, the fuel costs were increased in the model parameters $(\$$ per $\mathrm{KW} / \mathrm{h})$. The increase in fuel costs led to changes in the output parameters of the model.

Table 2 compares the total values of the nonconnected EPSs and interstate power interconnection scenarios with the possible economic recession in China and with the $\mathrm{CO}_{2}$ emission taxes are increased to $\$$ $60 /$ ton.

Table 2. Additional scenarios with $\mathrm{CO}_{2}$ emission taxes.

\begin{tabular}{|l|l|l|l|l|l|}
\hline \multirow{2}{*}{$\begin{array}{l}\text { Name of } \\
\text { scenario }\end{array}$} & \multicolumn{2}{|l|}{$\begin{array}{l}\text { Capital investments, } \\
\text { \$ Bln. }\end{array}$} & \multicolumn{2}{l|}{ Capacity, GW } \\
\cline { 2 - 6 } & $\begin{array}{l}\text { power } \\
\text { plants }\end{array}$ & $\begin{array}{l}\text { electric } \\
\text { ties }\end{array}$ & Total & $\begin{array}{l}\text { installed } \\
\text { capacity }\end{array}$ & additions \\
\hline $\begin{array}{l}\text { Non- } \\
\text { connection }\end{array}$ & 832 & 0,156 & 832 & 2189 & 432 \\
$\begin{array}{l}\text { EPSs, with } \\
\text { economic } \\
\text { recession } \\
\text { in China, } \\
\mathrm{CO}_{2} \text { tax is } \\
60 \text { \$ton }\end{array}$ & & & & & \\
\hline $\begin{array}{l}\text { Interstate } \\
\text { power } \\
\text { Interconne } \\
\text { ction, with } \\
\text { economic } \\
\text { recession } \\
\text { in China, } \\
\text { CO }{ }_{2} \text { tax is } \\
60 \text { \$tton }\end{array}$ & 784 & 32 & 816 & 2129 & 372 \\
\hline $\begin{array}{l}\text { Resulting } \\
\text { effect }\end{array}$ & 48 & -32 & 16 & 60 & \\
\hline
\end{tabular}

Figure 3 shows the structure of the contributions of each type of power plant to power generation in the NEA ISPG. Generation of coal-fired power plants is $61 \%$, primarily due to China's EPS. 


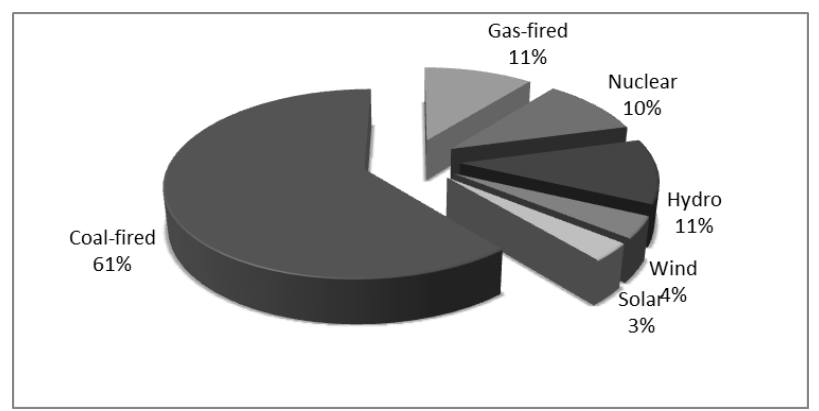

Fig. 3. Structure of the contributions of each type of power plant to power generation to the NEA ISPG.

Figure 4 shows a similar structure of contributions of each type of power plant to power generation in the NEA ISPG, with taking into account the $\mathrm{CO}_{2}$ emissions tax.

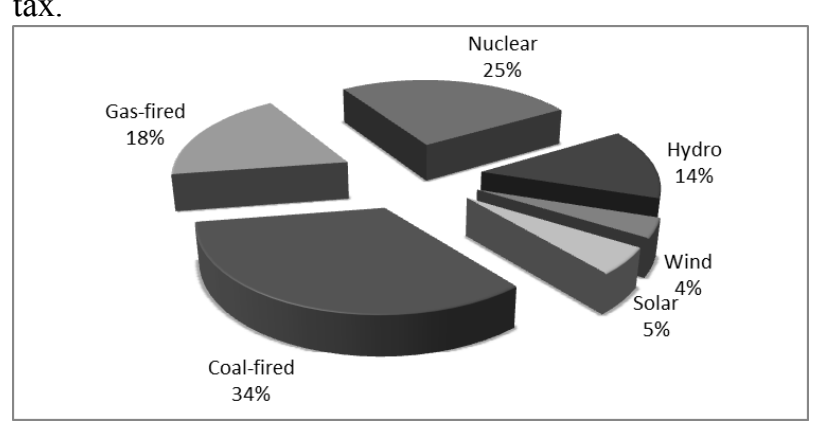

Fig. 4. Structure of the contributions of each type of power plant to power generation to the NEA ISPG with $\mathrm{CO}_{2}$ emissions tax.

As a result, after the maximum increase in fuel costs, the share of coal-fired generation decreased to $34 \%$. First of all, by increasing the generation of nuclear and gasfired power plants. The structure of installed capacities has also changed significantly, Figure 5.

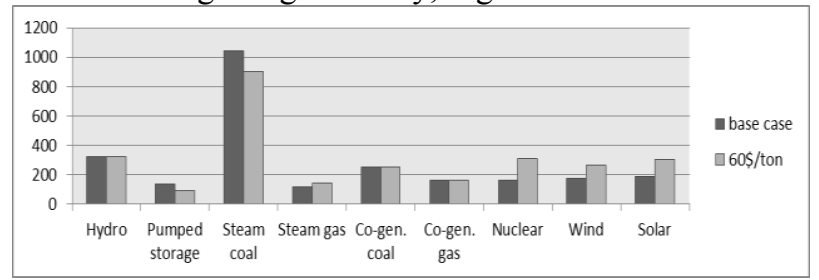

Fig. 5. Installed capacity structure. Comparison of two scenarios: with $\mathrm{CO}_{2}$ tax and without taxes.

Figure 5 shows a comparison of the structure of the optimized installed capacity. On the left, there are columns showing the installed capacities for the base case scenario. On the right is a scenario with an increased $\mathrm{CO}_{2}$ tax to $\$ 60 /$ ton. With an increase in the $\mathrm{CO}_{2}$ tax, additions of new capacity of coal-fired power plants are reduced. First of all, due to the additions of the capacity of nuclear power plants. When the upper limits of new additions of nuclear power plants are exhausted, new capacities of renewable energy sources - wind and solar power plants (WPP and SPP) are installed. A similar trend is shown by calculations for the scenario of possible China's economic recession, Figure 6.

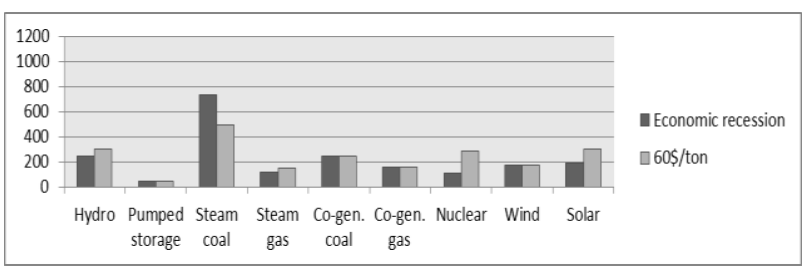

Fig. 6. Installed capacity structure. Comparison of two scenarios: with possible economic recession in China (left) and with $\mathrm{CO}_{2}$ emission taxes (right).

With a lower level of energy consumption in China for the target year 2040 and with an increase in the $\mathrm{CO} 2$ emissions tax, the capacity of coal-fired power plants is being supplanted by the capacities of nuclear power plants, wind power plants and solar power plants.

\section{Additional scenarios with the intermittence of power output of wind and solar power plants}

The specifics of optimizing the new capacities of wind and solar are the intermittence of their electric power output [9]. The ORIRES model for all other types of power plants optimizes not only the addition of new capacities, but also their power generation, taking into account the daily electric load graph for each node (power system).

In all previous scenarios, the profiles of daily power generation graphs of WPP and SPP in the model are fixed. The profile of the graphs of WPP and SPP in the solving process of the optimization problem does not change, but installed capacities can be optimized in a given range by minimizing the costs of the ISPG as a whole. For WPP and SPP, utilization hours and power output configuration are not optimized. Due to this, the hourly distribution of power output of WPP and SPP for each calculation is set by a fixed graph.

A number of additional experiments were carried out, in which the volume of the contribution of WPP and SPP to the total generation was varied, and the shape of their daily power generation graph was changed.

In these experiments, the graphs of electric load of WPP was changed for all electric power systems (EPS) of China for each of the four seasons of the year. Particularly, capacity factor of WPP is increased up to $40 \%$. Previously, for different nodes, depending on the year seasons, the capacity factor of WPP was ranged from $12 \%$ to $35 \%$.

As an example, the authors used the graph of electric load of WPP in Northeast and Center (NEC) of China, in the summer season, in which the capacity factor of WPP was $14 \%$, which corresponds to 3.3 utilization hours per day. For the experiment, this capacity factor of WPP was increased up to $40 \%$, which corresponds to 9.6 utilization hours. Figures 7 and 8 show correspondingly the above noted graphs of electric load of WPP for the NEC of China (summer). 


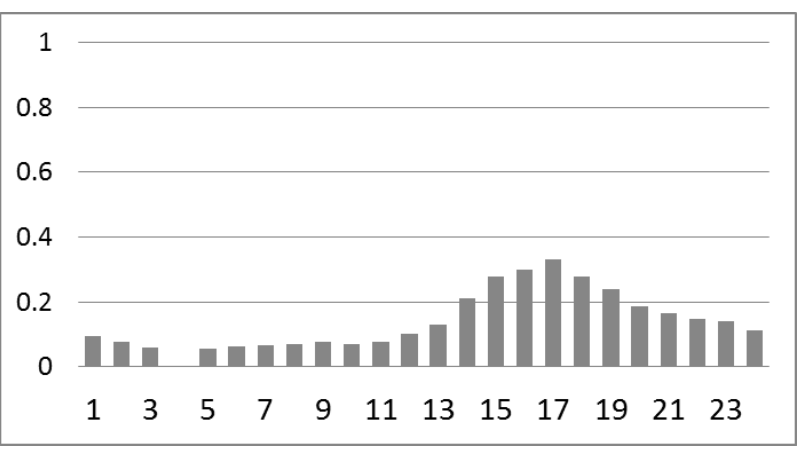

Fig. 7. Utilization hours of WPP are 3.3 (14\% capacity factor).

The second graph of the daily power generation of WPP differs from the first in that the area under it (reflecting generation for each of the 24 hours) corresponds to utilization (operating) hours is 9.6 per day. This is interpreted as an increase in the average total wind generation during the day.

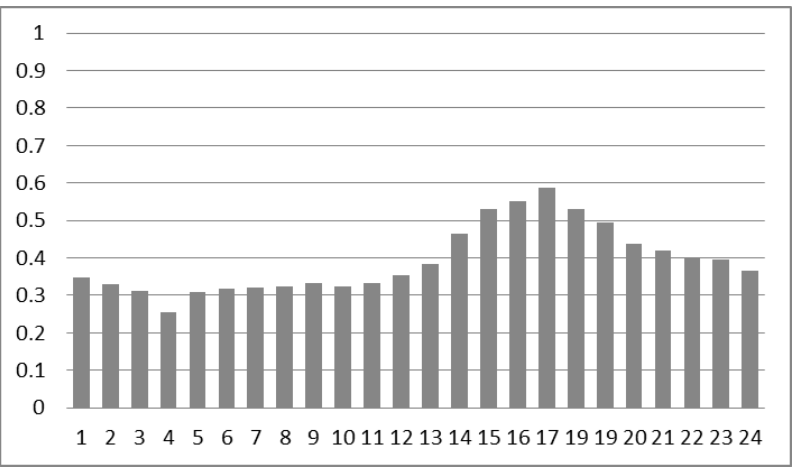

Fig. 8. Utilization hours of WPP are 9.6 (40\% capacity factor).

In order to study the effect of average annual changes in capacity factor on the optimal power generation structure, as an experiment, graphs with the utilization hours of 9.6 were set for the wind power plants of China. All 8 previous scenarios were recalculated with the specified characteristics for WPPs.

As can be seen from Figure 9, the structure of the contributions of each type of power plant to power generation has changed: the share of WPP generation increased to $9 \%$ due to a decrease in the share of fossil fuel generation.

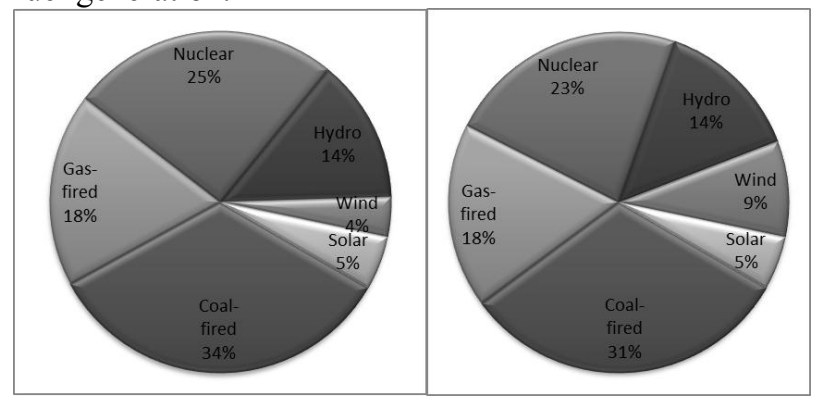

Fig. 9. Comparison of the structure of power plant contributions by fuel type (left - 14\% capacity factor and $40 \%$ capacity factor - right).

Table 3 shows a comparison of the main indicators of two scenarios in which the $\mathrm{CO}_{2}$ emission tax is 60 \$/ton, and they differ from each other by the increased utilization (operating) hours for WPP in China power systems.

Table 3. Scenarios comparison: normal and increased capacity factor.

\begin{tabular}{|l|l|l|l|l|l|l|}
\hline Name & \multicolumn{3}{|l|}{$\begin{array}{l}\text { Values of objective function, } \\
\text { \$ Bln./year }\end{array}$} & \multicolumn{2}{l|}{ Capacity, GW } \\
\cline { 2 - 7 } & $\begin{array}{l}\text { power } \\
\text { plant }\end{array}$ & $\begin{array}{l}\text { fuel } \\
\text { cost }\end{array}$ & $\begin{array}{l}\text { electric } \\
\text { ties }\end{array}$ & Total & Installed & addition \\
\hline $\begin{array}{l}\mathrm{CO}_{2} \text { tax } \\
60 \text { \$ton, } \\
\text { capacity } \\
\text { factor } \\
14 \%\end{array}$ & 236 & 364 & 0.02 & 600 & 236 & 364 \\
\hline $\begin{array}{l}\mathrm{CO}_{2} \text { tax } \\
60 \$ / \text { ton, } \\
\text { capacity } \\
\text { factor } \\
40 \%\end{array}$ & 237 & 345 & 0.02 & 583 & 237 & 345 \\
\hline $\begin{array}{l}\text { Resultin } \\
\text { g effect }\end{array}$ & -1 & 19 & 0 & 17 & -1 & 19 \\
\hline
\end{tabular}

As a result, a series of experiments on changing the profiles (configuration) of graphs of the electric load of WPP, with the same utilization hours, showed that these changes practically do not affect the solution of the optimization problem.

\section{Conclusions}

The experiments carried out showed:

The increase in the tax on $\mathrm{CO}_{2}$ emissions will cause, first of all, the replacement of new capacities of coalfired power plants with the new capacities of nuclear power plants. Only when the limit on their additions is exhausted, the addition of the new capacities of wind and solar power plants become profitable.

A possible recession in energy consumption in China does not change this relationship. However, at the same time, the decrease in new commissioning of coalfired power plants will probably be replaced by the conservation of existing coal-fired power plants.

Changes in the average annual utilization hours of wind and solar power plants affect only the structure of electricity generation. This leads, respectively, to a decrease or increase in the consumption of fossil fuel in the target year. At the same time, the structure of the addition of new capacities remains unchanged.

With the maximum increase in $\mathrm{CO}_{2}$ tax, the share of installed wind and solar capacities will increase to $22 \%$, compared to $10 \%$ in the basic scenarios (without the $\mathrm{CO}_{2}$ emission taxes).

The research was carried out under State Assignment Program No. III. 17.6.2 (AAAA-A17117030310447-3) of the Fundamental Research of Siberian Branch of the Russian Academy of Sciences and partly supported by the Russian Foundation of Basic Research, Grant No. 18-07-00495-A. 


\section{References}

1. Chudinova L. Yu., Podkovalnikov S. V. and Trofimov I. L. Multilateral cooperation for power interconnection in Northeast Asia // 10th International Conference on Asian Energy Cooperation «AEC 2017». E3S Web Conf, №27 (1) 2018, c. 20-28.

2. L.S. Belyaev, S.V. Podkovalnikov, V.A. Savelyev, Scientific report. The program for the development of hydropower in Russia until 2030 for the future until 2050. (2015) [in Russian]

3. L. Belyaev, L. Chudinova, O. Khamisov, G. Kovalev, L. Lebedeva, S. Podkovalnikov and V. Savelev, Studies of interstate electric ties in Northeast Asia, International Journal of Global Energy Issues, 17, 3 (2002)

4. L.S. Belyaev, S.V. Podkovalnikov, V.A. Savelyev, L.Yu. Chudinova, The effectiveness of interstate electric ties (Novosibirsk: Nauka, 2008) [in Russian]

5. S.V. Podkovalnikov, I.L. Trofimov, L.N. Trofimov, Technological aspects of a geoinformation computing system to support research in the formation of interstate power interconnections. Journal of software engineering. New technologies (2018) [in Russian]
6. I.L. Trofimov, L.N. Trofimov, software tools for the formation and analysis of many variants of the model calculations and presenting the results in the web application. Journal of information and Mathematical Technologies in Science and Management, 1, 17 (2020) [in Russian]

7. S.V. Podkovalnikov, I.L. Trofimov, L.N. Trofimov, L.Yu. Chudinova, L.S. Belyaev, V.A. Savelev, Computing and Information System for Research of Prospective Electric Power Grids Expansion, Yugoslav Journal of Operations Research, [S.l.], 29, 4 (2019)

8. P. Luckow, E. Stanton, S. Fields et al. Spring 2016 National Carbon Dioxide Price Forecast. Cambridge. Massachusetts. 2016. http://www.synapseenergy.com/sites/default/files/2016-Synapse-CO2Price-Forecast-66-008.pdf

9. L.N. Trofimov, I.L. Trofimov, The assessment of integration effects accounting the stochasticity of wind and solar power plants generation in the Asian Power Grid, Rudenko International Conference "Methodological problems in reliability study of large energy systems" (RSES 2019). E3S Web Conf., 139 (2019) 